\title{
The rate of adaptation of urea cycle enzymes, aminotransferases and glutamic dehydrogenase to changes in dietary protein intake
}

\author{
By T. K. DAS AND J. C. WATERLOW \\ Department of Human Nutrition, London School of Hygiene and Tropical Medicine, \\ Keppel Street (Gower Street), London WCI ${ }_{7} H T$ \\ (Received I6 November I973-Accepted 21 Fanuary 1974)
}

\begin{abstract}
1. Measurements were made, at $6 \mathrm{~h}$ intervals, of urinary nitrogen output and of the activity of some hepatic enzymes in the rat during adaptation from one level of dietary protein to another. The enzymes measured were arginase $(E C \quad 3 \cdot 5 \cdot 3 \cdot 1)$, argininosuccinate lyase $(E C 4.3 .2 .1)$, argininosuccinate synthetase $(E C$ 6.3.4.5), glutamate dehydrogenase $(E C$ I.4.1.2) and alanine and aspartate aminotransferases $(E C$ 2.6.1.2 and $E C$ 2.6.r.I $)$.

2. Completeness of urine collection, which was essential for these experiments, was checked by recovery of injected [ $\left.{ }^{131} I\right]$ iodide.

3. When the dietary protein content was reduced from 135 to $45 \mathrm{~g}$ casein $/ \mathrm{kg}$, the urinary $\mathrm{N}$ output and the activities of the hepatic enzymes reached their new steady-state levels in $30 \mathrm{~h}$. The reverse adaptation, from 45 to $135 \mathrm{~g}$ casein $/ \mathrm{kg}$, was also complete in $30 \mathrm{~h}$.

4. The rate of change of enzyme activity and the final activity as percentage of initial activity were very similar for all six enzymes, suggesting a common control mechanism. The calculated half-lives of the enzymes were of the order of $7 \mathrm{~h}$, which is very much shorter than those found by previous workers.

5. There was no simple relationship between the activity of the urea cycle enzymes and the amount of $\mathrm{N}$ excreted. When an equal amount of gelatin was substituted for casein the $\mathrm{N}$ output was doubled but there was no change in the activity of the liver enzymes.

6 . The results suggest that the activity of the urea cycle enzymes depends in part on the amount of $\mathrm{N}$ available for excretion after the demands for synthesis have been met. The enzymes, however, appear to be present in excess so that an increased $\mathrm{N}$ load was not necessarily accompanied by an increase in enzyme activity.
\end{abstract}

This paper is concerned with the mechanism by which urinary nitrogen output is adjusted to match the intake, and in particular with the part played in this process by adaptive changes in hepatic enzymes.

Schimke (1962) was the first to show that in the rat the activity of the urea cycle enzymes, as measured in vitro, is related to the level of dietary protein intake. This was fully confirmed by later work (Schimke, 1964; Harper, 1965 ; Stephen, r968). Schimke (1964) also found a rise in the activity of the urea cycle enzymes in starvation, when there is an increase in urinary $\mathrm{N}$ output as a result of the breakdown of tissue protein. McLean \& Gurney (1963) showed that the urea cycle enzymes are sensitive to adrenalectomy and to the administration of cortisone and growth hormone.

Similar adaptive changes are shown by enzymes in the liver which make amino groups available for entry into the urea cycle; alanine aminotransferase ( $E C$ 2.6.1 .2) (GPT); aspartate aminotransferase (EC 2.6.I.I) (GOT); and glutamate dehydrogenase (EC I . 4. I.2) (GDH) (Rosen, Roberts \& Nicol, r 959; Pitot, Potter \& Morris, I96r; Muramatsu \& Ashida, r962; Schimke, r962; Harper, 1965). The observations of Waterlow \& Patrick (1954) and of Stephen \& Waterlow (I968) suggested that many 
Table I. Composition of experimental diets given to rats $(\mathrm{g} / \mathrm{kg})$

\begin{tabular}{|c|c|c|c|c|}
\hline & \multicolumn{4}{|c|}{ Diet } \\
\hline & $\mathrm{C}_{5}$ & $\mathrm{C}_{14}$ & $\mathrm{C}_{24}$ & $\mathrm{GI}_{4}$ \\
\hline Casein & 45 & 135 & 230 & o \\
\hline Gelatin & 0 & 0 & 0 & I35 \\
\hline Maize starch & $763 \cdot 5$ & 673 & 577 & 674 \\
\hline Arachis oil & 45 & 45 & 45 & 45 \\
\hline Salt mixture* & 45 & 45 & 45 & 45 \\
\hline Solka Floc & 90 & 90 & 90 & 90 \\
\hline Methionine & 0.45 & I'3 & $2 \cdot 2$ & 0 \\
\hline \multicolumn{5}{|l|}{ Vitamins* } \\
\hline Water soluble & Io & 10 & 10 & 10 \\
\hline Fat soluble & I & $\mathbf{I}$ & $\mathbf{I}$ & $\mathbf{I}$ \\
\hline
\end{tabular}

* See Payne \& Stewart (1972).

of these liver enzymes adapt to dietary conditions in man in much the same way as in the rat.

In the experiments on rats referred to above, the adaptive enzyme changes were observed after the new diet had been fed for several days. In some of the experiments the output of $\mathrm{N}$ or of urea in the urine was measured at the same time (e.g. Stephen, I968). However, no observations appear to have been made during the actual period of adaptation from one level of protein intake to another. It is implied that the changes in activity of the urea cycle enzymes cause the changes in urea output, but for this to be accepted it must be shown that the time course of the two events is similar.

There is some information about the rate at which urinary $\mathrm{N}$ output changes in man after a change in $\mathrm{N}$ intake. In the well-nourished adult the new level is reached in 6-Io d (Martin \& Robison, I922; Scrimshaw, Hussein, Murray, Rand \& Young, I972), in the poorly-nourished adult 2-3 d (Gopalan \& Narasinga Rao, I966), and in the infant $2 \mathrm{~d}$ (Chan, 1968). We have found no comparable information about the rat.

In the experiments reported here, measurements were made of the activity of some liver enzymes and of urinary urea output at successive intervals of $6 \mathrm{~h}$ after the diet had been changed from high to low protein or vice versa. Since it was essential for the interpretation of the results that recovery of urinary $\mathrm{N}$ should be as complete as possible, preliminary experiments were done to test this point.

\section{MATERIALS AND METHODS}

\section{Animals and diets}

Black-and-white hooded male rats weighing $40-50 \mathrm{~g}$ were obtained from a commercial source.

The stock diet was 'Oxoid' cubes containing about $220 \mathrm{~g}$ protein $/ \mathrm{kg}$ (H. C. Styles Ltd, Bewdley, Worcestershire). The experimental diets contained 45 , I 35 or $230 \mathrm{~g}$ casein or $135 \mathrm{~g}$ gelatin/ $\mathrm{kg}$ (Table $\mathrm{I}$ ). The total daily ration of either to or $12 \mathrm{~g} / \mathrm{rat}$ was divided into four equal parts and given at $6 \mathrm{~h}$ intervals mixed with water to reduce spilling. 
The rats were first kept on the stock diet for about 2 weeks. After this standardization period they were given one of the synthetic diets for I week and trained to eat four equal meals/day to produce a constant feeding pattern. At the same time they were accustomed to solitary confinement in the metabolic cages. The cages, grids and funnels were made of galvanized iron (E. K. Bowman, type B7). In this pattern of cage, access to the food pot is by a tunnel, so that the rat cannot easily pass urine into it.

\section{Urine collection}

Glass separators wert attached to the outlets of the funnels to separate urine and faeces. Urine was collected into $100 \mathrm{ml}$ flasks containing Io $\mathrm{ml} \mathrm{I} \mathrm{M}-\mathrm{HCl}$. At the end of each collection period, usually $6 \mathrm{~h}$, the inner surface of the cage was washed down carefully with water to make a volume of $100 \mathrm{ml}$. This large volume was found to be essential for complete recovery.

To test the completeness of recovery, preliminary experiments were done in which $\left[{ }^{131} \mathrm{I}\right] \mathrm{KI}$ was administered. Provided that uptake by the thyroid is blocked, all the isotope given should be excreted in the urine. In these experiments the rats were fed on the stock diet $a d l i b$. As a further check creatinine output was measured daily for 2 weeks in seven rats given experimental diets, the protein content of the diet being changed in the course of the experiment.

\section{Tests of recovery with radioactive iodide}

[131 I]KI from the Radiochemical Centre, Amersham was made up to $10-20 \mu \mathrm{Ci} / \mathrm{ml}$ in normal saline. Of this solution, $0.5^{-1} \mathrm{ml}$ (accurately measured by weighing the syringe) was given by intraperitoneal injection. In some experiments the uptake of iodine by the thyroid was blocked by giving $0.05 \mathrm{~g} \mathrm{KI} / 1$ in drinking-water, together with the intraperitoneal injection of $0 \cdot 2-0.3 \mathrm{ml}$ isotonic $\mathrm{KI}$. Urine was collected into

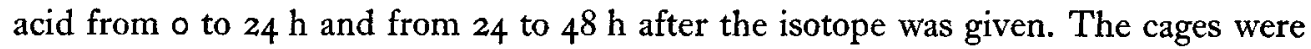
washed through in the usual way, and after it had been made to volume the diluted urine was counted in a well-type scintillation counter. Appropriate dilutions of the injected solution were counted as standards and to correct for decay.

\section{Chemical measurements on urine}

Total $\mathrm{N}$ was measured in a Technicon AutoAnalyzer by the phenol-hypobromite method (Technicon Instruments Corporation, 1967) after Kjeldahl digestion with selenium oxide as catalyst.

Urea concentration was measured by the diacetyl method (Wootton, I964).

Creatinine concentration was measured by Jaffe's reaction (Wootton, I964).

\section{Preparation of liver extracts and measurement of enzymes}

Rats were anaesthetized with chloroform and within 2 min the liver was removed, weighed, quickly frozen on solid $\mathrm{CO}_{2}$ and immediately stored at $-18^{\circ}$. The liver was taken out of the deep-freeze just before use, gently blotted on filter paper, and any visible ice removed carefully. Samples of liver, as appropriate for each assay, were 
homogenized in a glass homogenizer. Once the tissue extracts and homogenates had been prepared the estimations were done on the same day to avoid loss of activity.

For measurement of the urea cycle enzymes, extracts were prepared by the method of Brown \& Cohen (1959), except that arginase was activated by the addition of $\mathrm{MnSO}_{4} \cdot{ }_{4} \mathrm{H}_{2} \mathrm{O}(8 \mathrm{~g} / 1$ isotonic $\mathrm{NaCl}$ ), as recommended by McLean \& Gurney (1963). Three urea cycle enzymes were measured: arginase $(E C 3 \cdot 5 \cdot 3 \cdot \mathrm{r})$, argininosuccinate lyase $(E C 4 \cdot 3 \cdot 2 . \mathrm{I})$ and argininosuccinate synthetase $(E C 6.3 \cdot 4 \cdot 5)$. The reaction conditions were those of Brown \& Cohen (I959). Urea, which is the end-product in all assays, was measured by the method of Archibald (1945). The activity of arginase was not linear with protein concentration over the range studied, as found also by Brown \& Cohen (1959). This may be because of inhibition by ornithine formed in the course of the reaction, or because the assay conditions are those of partial first-order kinetics, as suggested by Brown, Brown \& Cohen (1959). For the other two enzymes activity was linear.

The unit of activity for the urea cycle enzymes was taken as the amount of enzyme catalysing the formation of $\mathrm{I} \mu \mathrm{mol}$ urea/min at $38^{\circ}$.

For measurement of GDH, GPT and GOT an aqueous homogenate was made containing $\mathrm{I} \mathrm{g}$ tissue in $9 \mathrm{ml}$ ice-cold distilled-water. The enzyme activities were determined from the rate of oxidation of NADH as described by Bergmeyer (1963). Measurements were made at $340 \mathrm{~nm}$ using a Unicam SP 8000 spectrophotometer (Pye Unicam Ltd, Cambridge). For all three assays the activity varied linearly with the amount of homogenate between 5 and $50 \mu \mathrm{l}$. As a check on the assay conditions tor these three enzymes a standard enzyme solution (Boehringer GmbH, Mannheim, Germany) was run in parallel, with the addition of all reagents but without homogenate. With these enzyme solutions there was good agreement between observed and expected rates of change in extinction at $340 \mathrm{~nm}$.

For GDH, GPT and GOT, one unit of activity was taken as the amount of enzyme which catalyses the oxidation of I $\mu \mathrm{mol} \mathrm{NADH} / \mathrm{min}$ at $25^{\circ}$.

\section{EXPERIMENTAL AND RESULTS}

\section{Completeness of urine collection}

Washing the cages daily with $100 \mathrm{ml}$ water produced almost complete recovery of injected $\left.{ }^{131} \mathrm{I}\right] \mathrm{KI}$, provided that the thyroid was blocked (Table 2).

The daily creatinine excretion was measured for 2 weeks in seven rats. The results are shown in Table 3. The variation between individual rats is rather large, and seems to be considerably greater than the within-litter SD recorded by Kumar, Land $\&$ Boyne (I959). There may have been variations between rats in fat content and lean-body mass, which were not measured. In accordance with the classical observations of Folin (1905), changes in the protein content of the diet had no effect on the creatinine excretion. This was shown by comparing results in the Ist and 2 nd week in rat nos. $32,33,35$ and 36 . This is contrary to the findings of Fisher ( 1965$)$; the discrepancy is probably due to differences in the method of urine collection, since Fisher apparently did not wash the cages with large volumes of water. The most relevant point for the 
Table 2. Recovery of ${ }^{131}$ I in urine, faeces and thyroid of rats of an intraperitoneal injection of $\left[{ }^{131} I\right] K I$, and blocking of the thyroid by the administration of unlabelled KI either in drinking-water or intraperitoneally

(Mean values with their standard errors where given)

$\begin{array}{lcc}\text { No. of rats } & \overbrace{\text { Oral }}^{\text {PI administration }} \\ \begin{array}{l}\text { Parenteral } \\ \text { Recovery of }{ }^{131} \mathrm{I}(\%):\end{array} & \text { ro } \\ \text { Urine } 0-24 \mathrm{~h} & 84 \pm 0.9 & 95 \pm \mathrm{r} \cdot \mathrm{I} \\ \text { 24-48 h } & 4 & \mathrm{r} \\ \text { Faeces } & \text { nd } & 3 \\ \text { Thyroid } & \text { nd } & 0.6 \\ \text { Total } & 88 & 99 \cdot 6 \\ & \end{array}$

Table 3. Daily urinary creatinine excretion ( $m g / 100 \mathrm{~g}$ rat per $d)$ for 2 weeks of seven rats given $10 \mathrm{~g} / \mathrm{d}$ of a diet containing $\circ(N), 5^{\circ}(L)$ or $100(H) \mathrm{g}$ casein $/ \mathrm{kg}$

(Mean value for $7 \mathrm{~d}$ and standard deviations between days for each rat)

\begin{tabular}{|c|c|c|c|c|c|c|}
\hline \multirow[b]{3}{*}{ Rat no. } & \multicolumn{3}{|c|}{$\mathrm{I}-7 \mathrm{~d}$} & \multicolumn{3}{|c|}{$8-I 4 d$} \\
\hline & \multirow[t]{2}{*}{ Diet } & \multicolumn{2}{|c|}{$\begin{array}{l}\text { Creatinine } \\
\text { excretion }\end{array}$} & \multirow[t]{2}{*}{ Diet } & \multicolumn{2}{|c|}{$\begin{array}{l}\text { Creatinine } \\
\text { excretion }\end{array}$} \\
\hline & & Mean & $\mathrm{SD}$ & & Mean & $\mathrm{SD}$ \\
\hline $3 I$ & $\mathbf{H}$ & 2.45 & 0.26 & $\mathbf{H}$ & $2 \cdot 4^{6}$ & 0.25 \\
\hline 32 & $\mathrm{H}$ & $2 \cdot 65$ & 0.19 & L & $2 \cdot 67$ & 0.18 \\
\hline 33 & L & $2 \cdot 80$ & 0.06 & $\mathrm{H}$ & 2.90 & 0.05 \\
\hline 34 & L & $2 \cdot 38$ & 0.29 & L & $2 \cdot 39$ & 0.28 \\
\hline 35 & $\mathbf{N}$ & 3.05 & 0.15 & $\mathrm{H}$ & $2 \cdot 75$ & 0.38 \\
\hline 36 & $\mathrm{~N}$ & $3 \cdot 35$ & O.II & $\mathbf{L}$ & $3 \cdot 39$ & 0.10 \\
\hline 37 & $\mathbf{N}$ & $\begin{array}{r}4.01 \\
0.01\end{array}$ & 0.06 & $\mathbf{N}$ & 4.02 & 0.18 \\
\hline
\end{tabular}

present purpose is the day-to-day variation. One would expect that the greater the errors in urine collection, the greater the day-to-day variability. The average coefficient of variation for each rat was about $7 \%$, which agrees quite well with the variability in creatinine excretion usually found in daily collections in man (Waterlow, Neale, Rowe \& Palin, 1972).

Effect of changing the protein content of the diet on urinary $N$ output and hepatic enzyme activity

Expt $\mathrm{I}$. In this experiment the effect of reducing the casein content of the diet from ${ }_{35}\left(\mathrm{C}_{14}\right)$ to $45\left(\mathrm{C}_{5}\right) \mathrm{g} / \mathrm{kg}$ was tested. The mean initial weight of the rats at the beginning of the period of stabilization on the stock diet was II2 g. Sixteen rats were changed from $\mathrm{C}_{14}$ to $\mathrm{C}_{5}$; seven rats were kept on each diet throughout. Urine was collected for successive $6 \mathrm{~h}$ periods from one rat in each of the groups maintained on $\mathrm{C}_{14}$ and $\mathrm{C}_{5}$ throughout, and initially from ten rats of the sixteen in the group whose diet was changed. Three rats were killed at the end of each $6 \mathrm{~h}$ period. Therefore after 


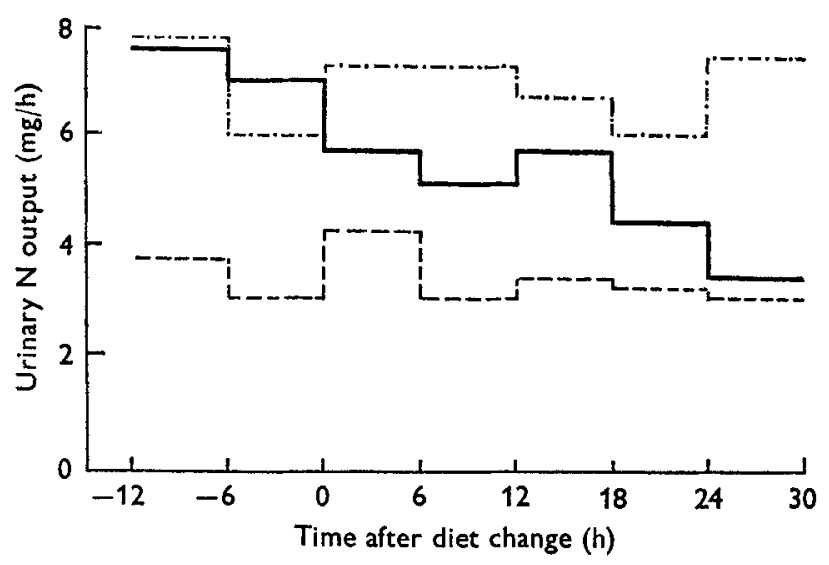

Fig. I. Expt I. Urinary nitrogen output of ten rats over $6 \mathrm{~h}$ periods after transfer from a diet containing $\mathrm{I}_{35} \mathrm{~g}$ casein $/ \mathrm{kg}\left(\mathrm{C}_{\mathrm{I}_{4}}\right)$ to one containing $45 \mathrm{~g}$ casein/ $\mathrm{kg}\left(\mathrm{C}_{5}\right)(\longrightarrow)$ and of one rat maintained throughout on $\mathrm{C}_{4}(-\cdots)$ and one rat maintained on $\mathrm{C}_{5}(---)$.
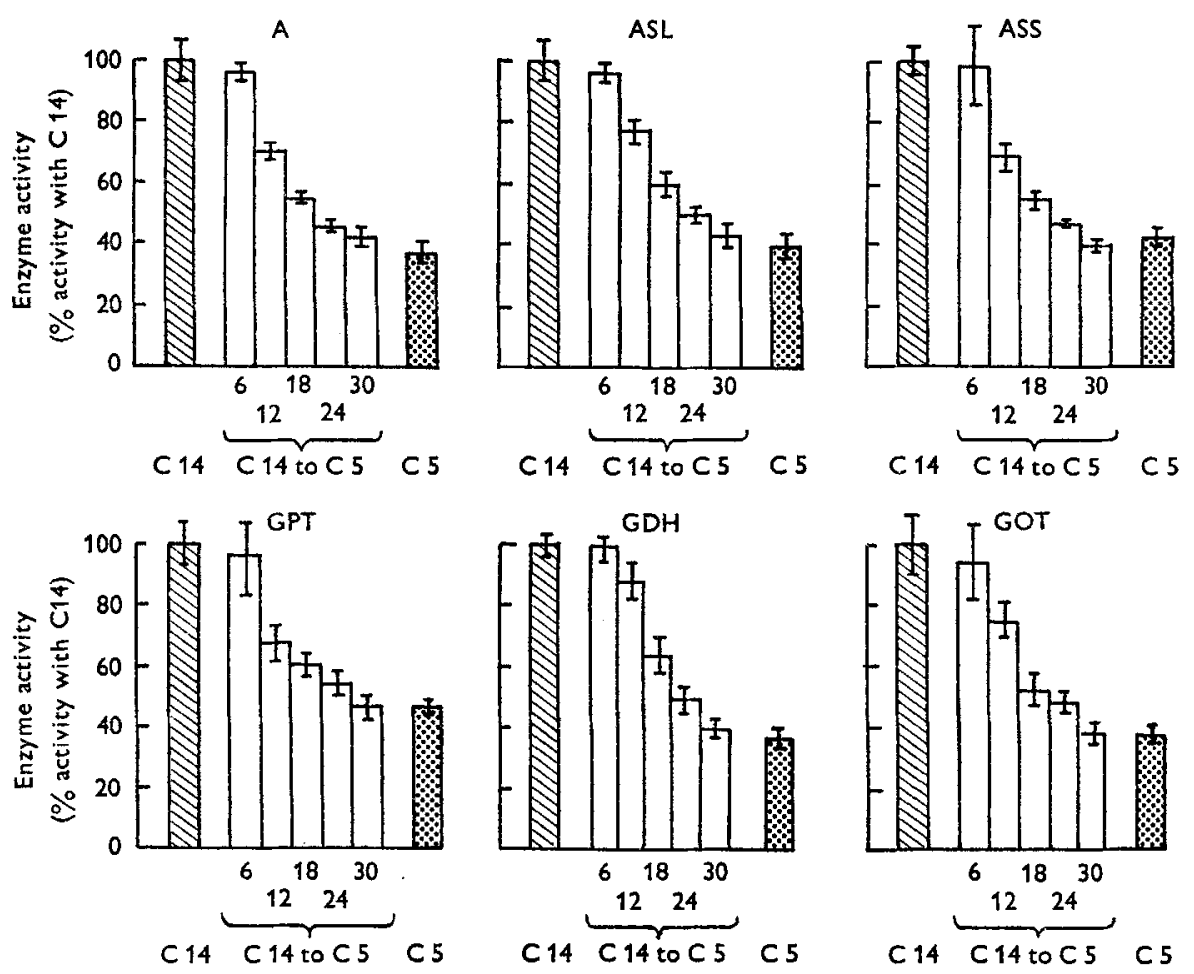

Fig. 2. Expt I. Mean values and ranges (vertical bars) for enzyme activity (per $g$ liver) in rats at $6,12,18,24$ and $30 \mathrm{~h}$ after transfer from a diet containing $\mathrm{I}_{35} \mathrm{~g}$ casein $/ \mathrm{kg}\left(\mathrm{C}_{14}\right)$ to one containing $45 \mathrm{~g}$ casein $/ \mathrm{kg}\left(\mathrm{C}_{5}\right)$ and in rats maintained on either $\mathrm{C}_{4}$ or $\mathrm{C}_{5}$ throughout. $\mathbb{N}$, activity in five rats maintained on $\mathrm{C}_{4}$; 橉, activity in five rats maintained on $\mathrm{Cr}_{4} ; \square$, activity in groups of three rats transferred from $\mathrm{C}_{14}$ to $\mathrm{C}_{5}$. A, arginase; $\mathrm{ASL}$, argininosuccinate lyase; ASS, argininosuccinate synthetase; GPT, alanine aminotransferase; GDH, glutamate dehydrogenase; GOT, aspartate aminotransferase. 
Table 4. Expt $\mathrm{I}$. Total activities per liver of six enzymes at $6 \mathrm{~h}$ intervals in rats after change from diet containing $\mathrm{I} 35 \mathrm{~g}$ casein/ $\mathrm{kg}\left(\mathrm{C}_{\mathrm{I}} 4\right)$ to diet containing $45 \mathrm{~g}$ casein $/ \mathrm{kg}\left(\mathrm{C}_{5}\right)$, expressed as \% of activity in control rats maintained on diet $C \mathrm{I}_{4}$
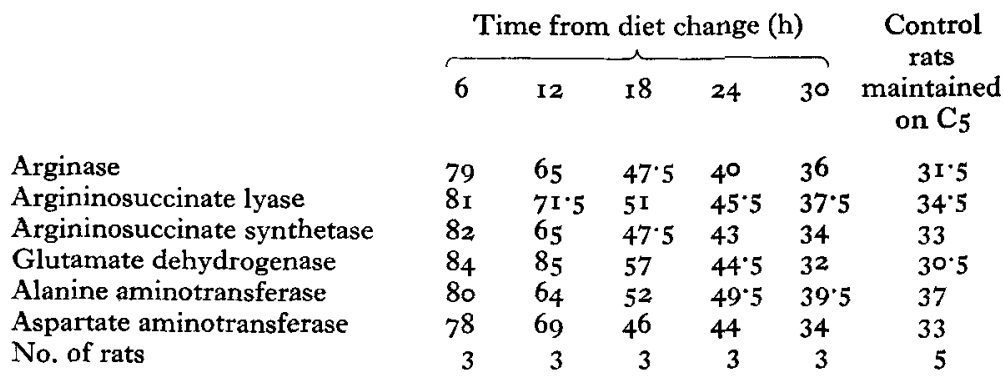

$\begin{array}{rlllll}79 & 65 & 47 \cdot 5 & 40 & 36 & 31 \cdot 5 \\ 81 & 71 \cdot 5 & 51 & 45 \cdot 5 & 37 \cdot 5 & 34 \cdot 5 \\ 82 & 65 & 47 \cdot 5 & 43 & 34 & 33 \\ 84 & 85 & 57 & 44 \cdot 5 & 32 & 3 \cdot \cdot 5 \\ 80 & 64 & 52 & 49 \cdot 5 & 39 \cdot 5 & 37 \\ 78 & 69 & 46 & 44 & 34 & 33 \\ 3 & 3 & 3 & 3 & 3 & 5\end{array}$

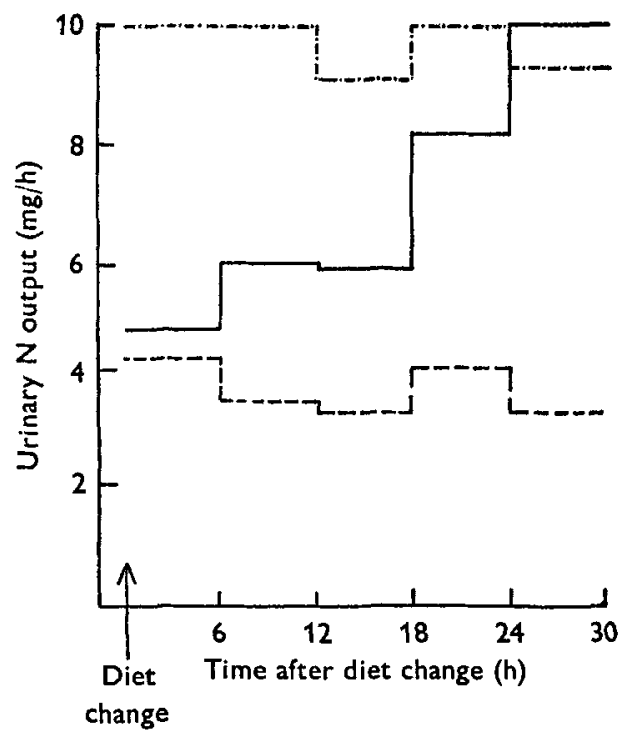

Fig. 3. Expt 2. Urinary nitrogen output in six rats over $6 \mathrm{~h}$ periods after transfer from a diet containing $45 \mathrm{~g}$ casein/ $/ \mathrm{kg}\left(\mathrm{C}_{5}\right)$ to one containing $\mathrm{I}_{35} \mathrm{~g}$ casein/ $/ \mathrm{kg}\left(\mathrm{C}_{14}\right)(-)$ and two groups of two rats, one maintained on $\mathrm{C}_{5}(---)$ and the other on $\mathrm{C}_{14}$ throughout $(-\cdot-)$.

$\mathrm{I} 8 \mathrm{~h}$ only seven rats were left, and the number available for urine collection became progressively smaller.

The time-course of the change in urinary $\mathrm{N}$ output is shown in Fig. $\mathrm{I}$; the new level was reached between 24 and $30 \mathrm{~h}$.

The time-course of the change in activity of hepatic enzymes is shown in Fig. 2. Adaptation to the new level appears to be complete in $30 \mathrm{~h}$, and all six enzymes changed at a similar rate and to a similar degree. The changes in total enzyme activity/liver were somewhat greater than the changes in activity/g liver, because the mean liver weight fell by $15 \%$, from $7.2 \mathrm{~g}$ in rats given $\mathrm{C}_{14}$ to $6.1 \mathrm{~g}$ in rats given $\mathrm{C}_{5}$. The percentage changes in total activity are summarized in Table 4.

Expt 2. In this experiment the opposite change was examined: rats were transferred 

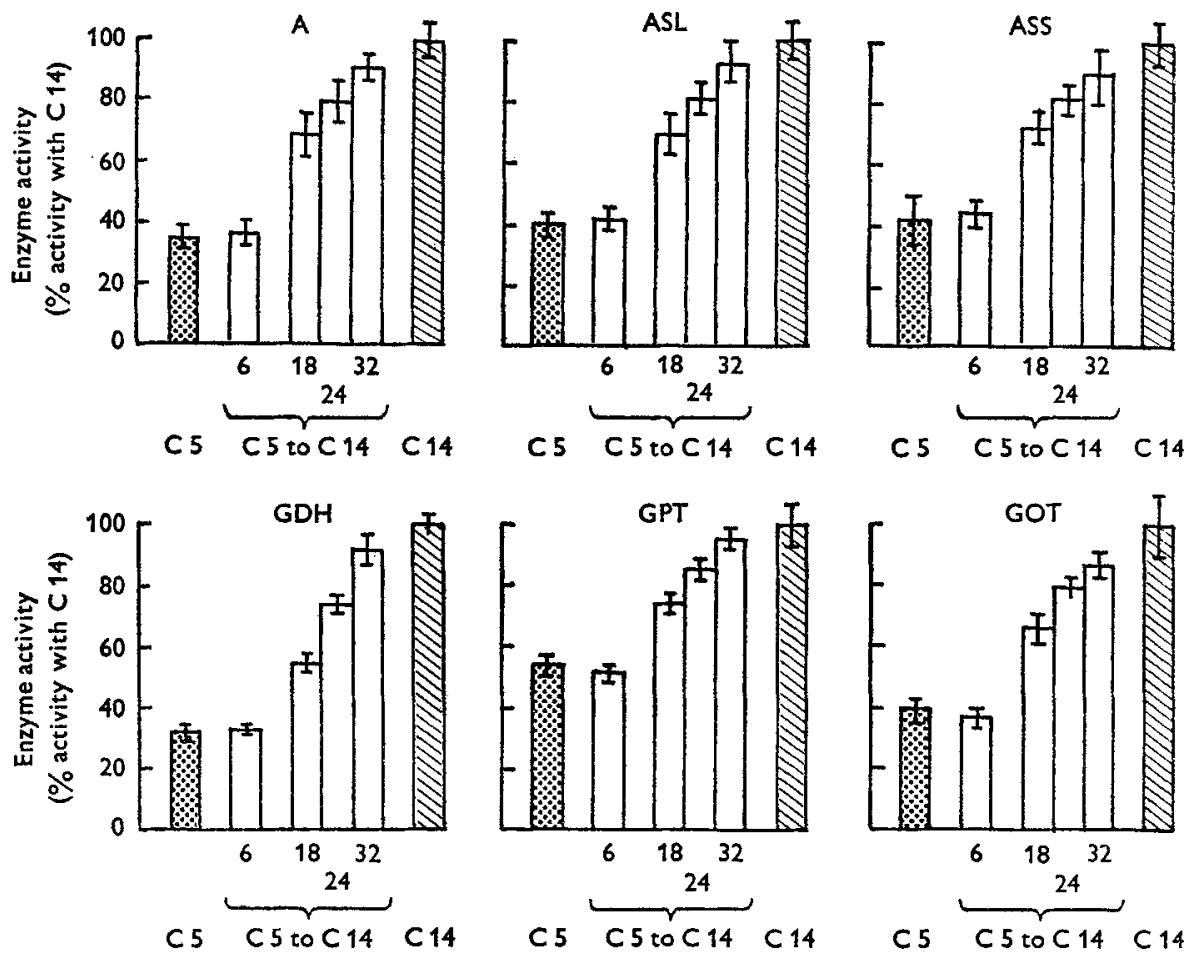

Fig. 4. Expt 2. Mean values and ranges (vertical bars) for enzyme activity (per $\mathrm{g}$ liver) in rats at $6,18,24$ and $32 \mathrm{~h}$ after transfer from a diet containing $45 \mathrm{~g}$ casein $/ \mathrm{kg}\left(\mathrm{C}_{5}\right)$ to one containing $135 \mathrm{~g}$ casein $/ \mathrm{kg}\left(\mathrm{Cr}_{4}\right)$ and in rats maintained on either $\mathrm{C}_{5}$ or $\mathrm{Cr}_{4}$ throughout. $\square$, activity in four rats maintained on $\mathrm{C}_{14}$; 国, activity in seven rats maintained on $C_{5} ; \square$, activity in groups of four rats transferred from $\mathrm{C}_{14}$ to $\mathrm{C}_{5}$. A, arginase; ASL, argininosuccinate lyase; ASS, argininosuccinate synthetase; GPT, alanine aminotransferase; $\mathrm{GDH}$, glutamate dehydrogenase; GOT, aspartate aminotransferase.

from diet $\mathrm{C}_{5}$ to diet $\mathrm{C}_{\mathbf{1}}$. The design of the experiment was the same as that of Expt I, except that the rats were younger, weighing only 50-6o $g$ when they were first given the stock diet. Sixteen rats were changed from $\mathrm{C}_{5}$ to $\mathrm{C}_{14}$, and seven rats were kept on each of these diets throughout.

Fig. 3 shows that the urinary $N$ output had reached its new level in $30 \mathrm{~h}$. The rats whose diet was changed were killed at $32 \mathrm{~h}$. At this time (Fig. 4) the activities of the liver enzymes had nearly, but not quite, reached the levels found in the rats maintained on $\mathrm{C}_{14}$ throughout. Again it is apparent that the activities of all six enzymes changed at similar rates. The mean liver weight increased by $20 \%$ during the period of adaptation, from $3.6 \mathrm{~g}$ in rats given $\mathrm{C}_{5}$ to $4.5 \mathrm{~g}$ in rats given $\mathrm{C}_{14}$. The percentage changes in total activity are summarized in Table 5 .

In this experiment, by mishap, no values were obtained for enzyme activities at i $2 \mathrm{~h}$ after the change of diet. Therefore, to obtain more results for the rate of change of enzyme activity, a subsidiary experiment ( $2 \mathrm{~A}$ ) was done with twenty-four rats, of mean initial weight $40 \mathrm{~g}$. Four rats were kept throughout on each of the standard diets ( $\mathrm{C}_{14}$ and $\mathrm{C}_{5}$ ). Sixteen rats were given $\mathrm{C}_{5}$ for a week and then changed to $\mathrm{C}_{14}$. Groups of rats were killed at $3 \mathrm{~h}$ intervals from 6 to $\mathrm{I} 8 \mathrm{~h}$, and then at $6 \mathrm{~b}$ intervals up 
Table 5. Expt. 2. Total activities per liver of six enzymes at $6 \mathrm{~h}$ intervals in rats after change from a diet containing $45 \mathrm{~g}$ casein $\mathrm{kg}\left(C_{5}\right)$ to a diet containing $\mathrm{I}_{35} \mathrm{~g}$ casein $/ \mathrm{kg}$ $(C \mathrm{I} 4)$ expressed as \% of activity in control rats maintained on diet $C \mathrm{I}_{4}$

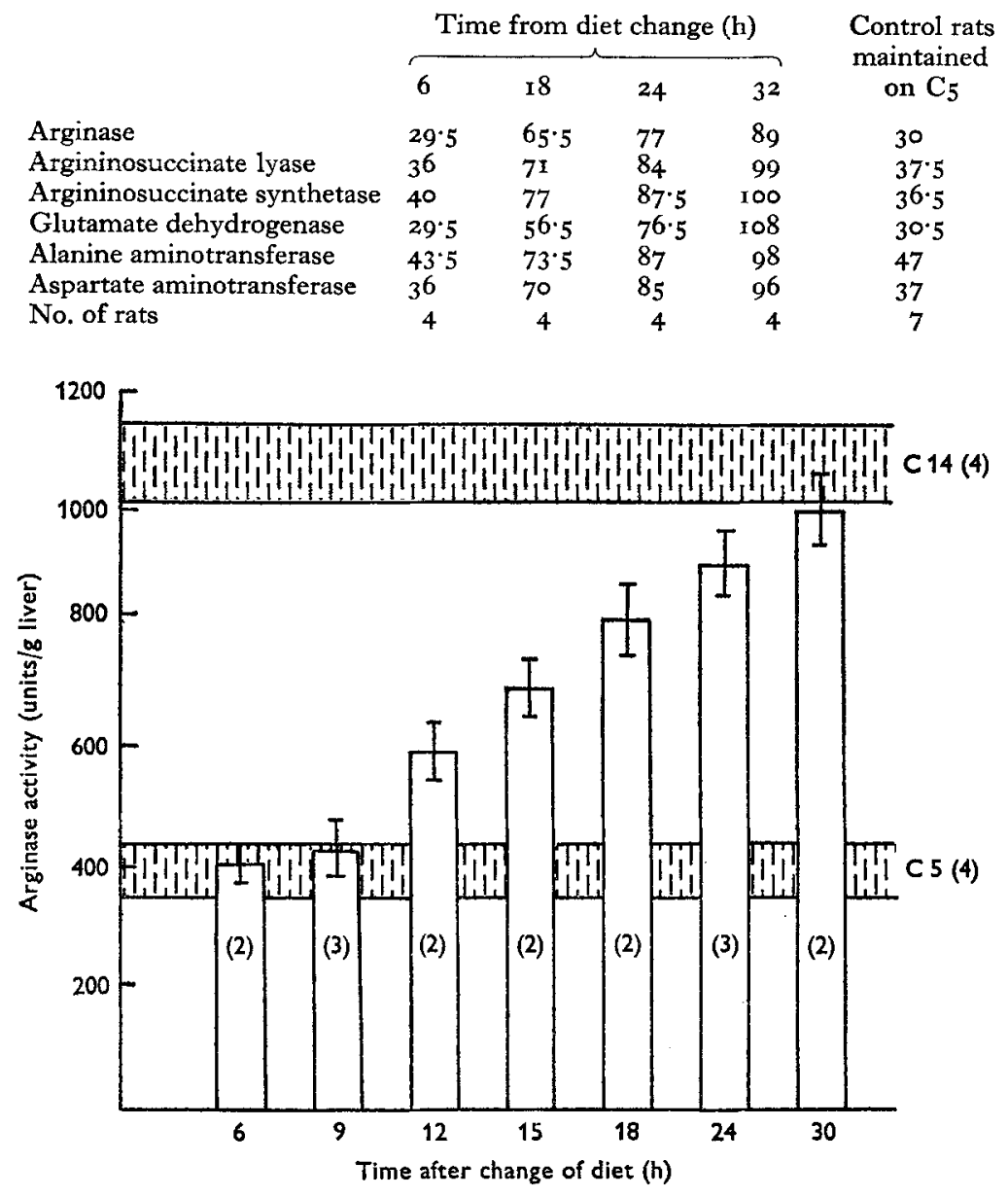

Fig. 5. Expt $2 \mathrm{~A}$. Mean values and ranges (vertical bars) for arginase activity (per $g$ liver) in rats at $6,9,12,15,18,24$ and $30 \mathrm{~h}$ after transfer from a diet containing $45 \mathrm{~g}$ casein $/ \mathrm{kg}\left(\mathrm{C}_{5}\right)$ to one containing ${ }_{3} 35 \mathrm{~g}$ casein $/ \mathrm{kg}\left(\mathrm{Cr}_{4}\right)$ and in rats maintained on either $\mathrm{C}_{5}$ or $\mathrm{Cr}_{4}$ throughout. The horizontal bands represent the range of activity in rats maintained on either $\mathrm{C}_{14}$ or $\mathrm{C}_{5}$ throughout. $\square$, Mean values and ranges (vertical bars) of activity in rats after change in diet; no. of rats in parentheses. One unit of arginase activity is the amount of enzyme catalysing the formation of $\mathrm{I} \mu \mathrm{mol}$ urea/min at $38^{\circ}$.

to $30 \mathrm{~h}$ after the change of diet. No urine was collected in this experiment, and only arginase activity was measured. The values for arginase activity are shown in Fig. 5 .

\section{Rate of change of enzyme activity}

In many studies of enzyme induction the kinetics of the process have been examined by plotting against time the logarithm of the difference between final enzyme activity 
Time from diet change (h)

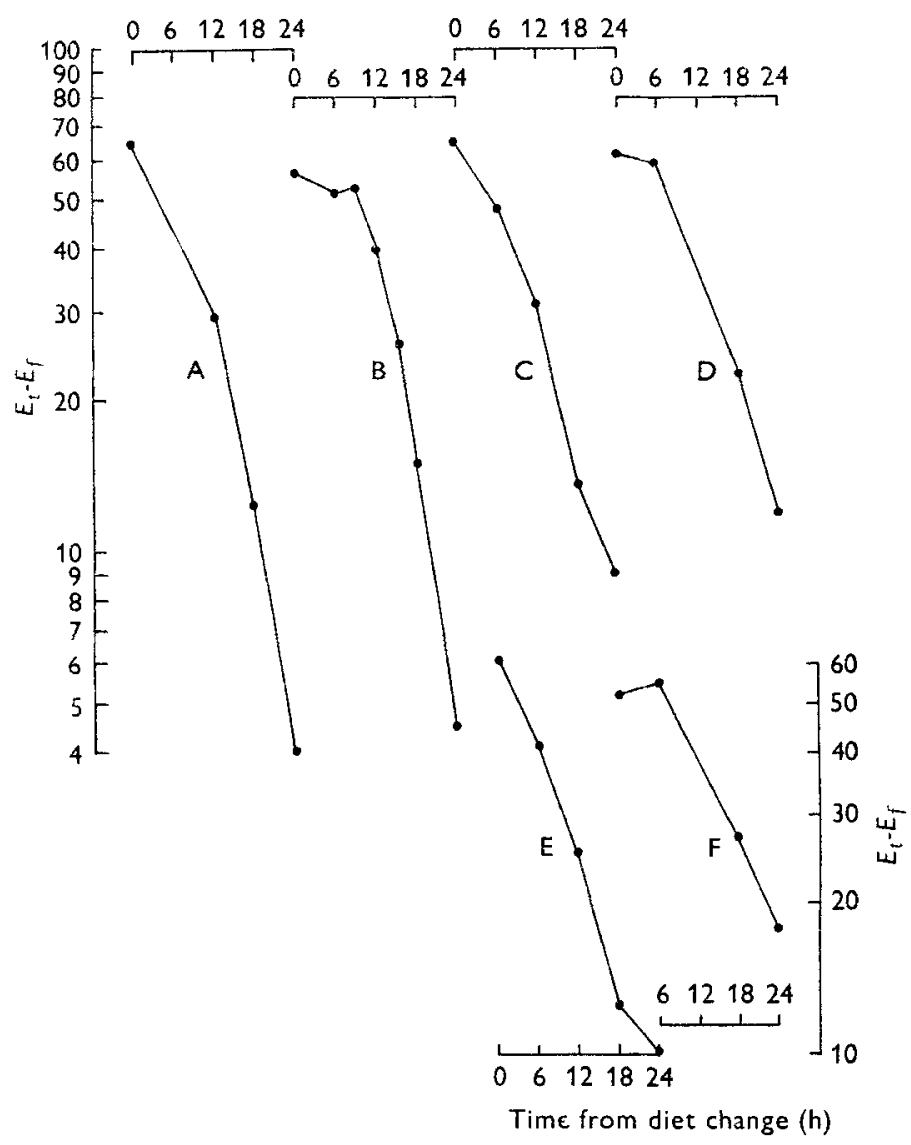

Fig. 6. Expts $I, 2$ and 2 A. Semilog plot of total enzyme activity (per liver) during adaptation to change in the protein content of diet. $E_{t}$, enzyme activity at time $t ; E_{f}$, enzyme activity at $3 \circ \mathrm{h} ; \mathrm{A}, \mathrm{C}, \mathrm{E}$, results from Expt I (rats transferred from a diet containing I $35 \mathrm{~g}$ casein $/ \mathrm{kg}$ (Cr 4 ) to one containing $45 \mathrm{~g}$ casein $/ \mathrm{kg}\left(\mathrm{C}_{5}\right)$ at time $t=0$ ); B, D, F, results from Expts 2 and $2 \mathrm{~A}$ (rats transferred from $\mathrm{C}_{5}$ to $\mathrm{C}_{4} 4$ at time $t=0$ ); $\mathrm{A}$ and $\mathrm{B}$, arginase; $\mathrm{C}$ and $\mathrm{D}$, argininosuccinate synthetase; $\mathrm{E}$ and $\mathrm{F}$, alanine aminotransferase.

$\left(E_{f}\right)$ and activity at time $t\left(E_{t}\right)$ (Segal \& Kim, 1963; Freedland, 1968; Schimke, 1970). In this method of analysis, which can be applied both when the enzyme is increasing and decreasing, two assumptions are made: (I) synthesis follows zero-order kinetics, breakdown follows first-order kinetics. Therefore in a steady-state, $k E=S$, where $E=$ amount of enzyme (units/liver); $k=$ fractional rate of breakdown (units/h); $S=$ rate of synthesis (units $/ \mathrm{h}$ ). When a new steady-state is reached after adaptation, $k^{\prime} E^{\prime}=S^{\prime} ;(2)$ when conditions are changed, any change in the rate of either synthesis or breakdown occurs instantaneously. If this is so, the plot of $\log \left(E_{t}-E_{f}\right)$ against time will be linear, and its slope depends only on the value of $k$. The steady-state value of $E$ depends on both $k$ and $S$.

In a preliminary communication (Das, 1972) it was shown that when enzyme concentrations (units/g) were plotted in this way, after a lag period of 6-9 h the slopes for 
Table 6. Half-lives of six liver enzymes calculated from changes in total activity after decrease in dietary protein from $\mathrm{I} 35$ to $45 \mathrm{~g}$ casein $/ \mathrm{kg}$ diet (Expt $\mathrm{I})$ or increase in dietary protein from 45 to $135 \mathrm{~g}$ casein/ $\mathrm{kg}$ diet (Expt 2)

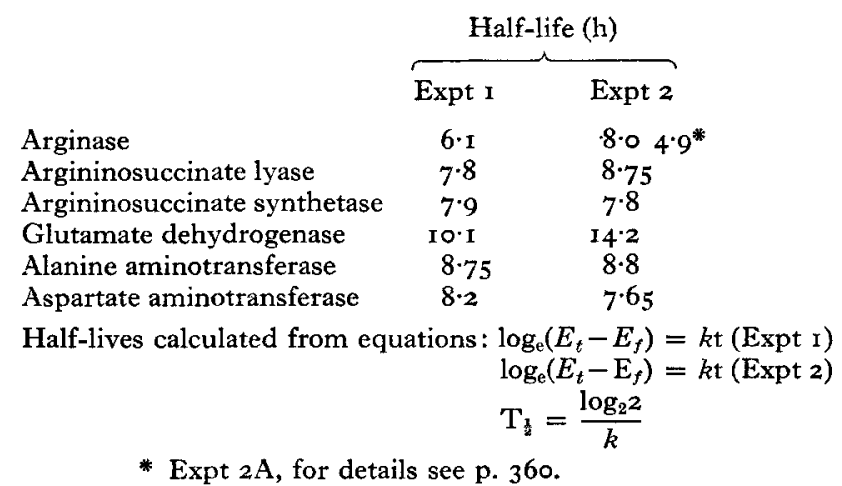

arginase were very nearly the same, whether the enzyme concentration was decreasing (Expt 1 ) or increasing (Expt $2 \mathrm{~A}$ ). The half-lives were $6 \cdot 7$ and $7 \cdot 2 \mathrm{~h}$. The slopes for the changes in concentration of the other enzymes were similar.

It seems more meaningful, however, to consider the changes in total activity rather than in concentration. Fig. 6 shows some examples from Expts I and 2, plotted from the values in Tables 4 and 5. As Freedland (1968) has pointed out, in this type of analysis the choice of the base-line value for $E_{f}$ is crucial. It would be logical in Expt $I$ (diet $\mathrm{C}_{14}$ changed to diet $\mathrm{C}_{5}$ ) to take the base-line activity $\left(E_{f}\right)$ as that observed in rats given diet $\mathrm{C}_{5}$ throughout and vice versa in Expt 2 (diet $\mathrm{C}_{5}$ changed to diet $\mathrm{C}_{14}$ ). However, when this is done, the difference between $E_{f}$ and $E_{t}$ at $30 \mathrm{~h}$ is very small (see Tables 4 and 5 ), and subject to great error. 'This has a disproportionate effect on the slopes. Therefore the value at $30 \mathrm{~h}$ in Expt $\mathrm{I}$, and at $32 \mathrm{~h}$ in Expt 2, has been taken as the base-line for these semilog plots.

Fig. 6 shows that in Expt I, when the dietary protein was reduced, there was an immediate fall in the amount of enzyme, with no lag period. All six enzymes behaved in the same way. On the other hand, in Expt 2, when the dietary protein was increased, there was a lag period of about $6 \mathrm{~h}$. Again, all six enzymes behaved similarly.

Even allowing for the lag period, the points do not fall exactly on straight lines. One reason for this is experimental error. In Expt 2 in particular, because of the lag the initial point for calculating the slopes was taken as the value at $6 \mathrm{~h}$. Since in addition the $\mathrm{I} 2 \mathrm{~h}$ values were missing, the slopes are based on only three points. A second reason for non-linearity is incorrect choice of base-line. It would be possible to compute in each instance the value for $E_{f}$ which gave the best approximation to a straight line, but this would serve no useful purpose. A third reason may be that the model is an oversimplification, and that changes in rates of synthesis or breakdown do not occur instantaneously. The lag period in Expt 2 is evidence of this.

In spite of these sources of error, calculation of the rate constants from the semilog plots, as if they were straight lines, gives at least an indication of the breakdown rates 
Table 7. Expt 3. Urinary nitrogen output and total liver enzyme activities in rats changed from a diet containing casein ( $135 \mathrm{~g} / \mathrm{kg} ; \mathrm{C}_{\mathrm{I} 4}$ ) to a diet containing gelatin (1 $35 \mathrm{~g} / \mathrm{kg}$; $G$ I4)

\begin{tabular}{|c|c|c|c|}
\hline & $\begin{array}{c}\mathrm{C}_{I_{4}} \\
\text { throughout }\end{array}$ & $\begin{array}{c}24 \mathrm{~h} \text { after } \\
\text { diet changet }\end{array}$ & $\begin{array}{c}\mathrm{GI}_{4} \\
\text { throughout }\end{array}$ \\
\hline \multicolumn{4}{|c|}{ Urinary $\mathrm{N}$ output (mg/rat per h) } \\
\hline Mean & $4 \cdot 9$ & 7.0 & 8.9 \\
\hline SD & 0.20 & - & 0.68 \\
\hline No. of collection periods & I0 & 2 & I 2 \\
\hline Body-weight* (g) & 86 & 92 & $9 \mathrm{I}$ \\
\hline No. of rats & 6 & 4 & 3 \\
\hline \multicolumn{4}{|l|}{ Total enzyme activity (units/liver) $\dagger$} \\
\hline Arginase & 4420 & 3970 & 3590 \\
\hline Argininosuccinate lyase & $20 \cdot 8$ & $18 \cdot 7$ & $18 \cdot 5$ \\
\hline Argininosuccinate synthetase & I I 7 & I0.9 & $9 \cdot 8$ \\
\hline Glutamate dehydrogenase & IOI & 100 & 87 \\
\hline Alanine aminotransferase & 218 & 209 & I83 \\
\hline Aspartate aminotransferase & 355 & 329 & 300 \\
\hline
\end{tabular}

* At time of killing.

$\dagger$ For arginase, argininosuccinate lyase and argininosuccinate synthetase, one unit of activity is the amount of enzyme catalysing the formation of $\mathrm{x} \mu \mathrm{mol}$ urea $/ \mathrm{min}$ at $38^{\circ}$. For glutamate dehydrogenase, alanine and aspartate aminotransferases, one unit of activity is the amount of enzyme catalysing the oxidation of I $\mu \mathrm{mol} \mathrm{NADH} / \mathrm{min}$ at $25^{\circ}$.

I Urine collected from $\mathrm{I} 8-24 \mathrm{~h}$ after change of diet.

of the enzymes. The results, expressed as half-lives, are summarized in 'Table 6 . With one or two exceptions the half-lives of all six enzymes are similar, and appear to be much the same whether enzyme activity is increasing or decreasing. It follows from this that the new steady-state must be achieved in the main by a change in the rate of synthesis rather than of breakdown.

The effect of protein quality on nitrogen output and on the activity of hepatic enzymes

The next experiments were designed to determine whether an increase in $\mathrm{N}$ output produced by feeding a poor-quality protein was accompanied by a parallel increase in the activity of the six liver enzymes which were measured in the previous experiments.

Expt 3. Sixteen rats weighing initially 50-60 g were given diet $\mathrm{C}_{14}$ for $6 \mathrm{~d}$, and were then transferred to a diet containing ${ }^{3} 35 \mathrm{~g}$ gelatin/kg (GI4). Urine was collected for $6 \mathrm{~h}$ periods, and three or four rats were killed at the end of each period. Control groups were given $\mathrm{C}_{4} 4$ and $\mathrm{G} \mathrm{I}_{4}$ throughout.

Table 7 shows that in rats given $\mathrm{G}$ I4 diet the urinary $\mathrm{N}$ excretion was almost twice as high as with the $\mathrm{C}_{14}$ diet. On transfer from the $\mathrm{C}_{14}$ diet to the $\mathrm{G}_{14}$ diet, the $\mathrm{N}$ excretion rose rapidly. Unfortunately, in this group urine collection was not continued for more than $24 \mathrm{~h}$. In spite of the rise in $\mathrm{N}$ the total enzyme activities fell slightly. In this instance, therefore, in contrast to previous experiments, there was a dissociation between changes in urinary $\mathrm{N}$ and enzyme activity.

Expt 4. These observations were confirmed by a further experiment in which the protein quality of the diet was changed in the opposite direction. Nine rats were given $\mathrm{G}_{14}$ for $6 \mathrm{~d}$ and then transferred to $\mathrm{C}_{14}$. Two rats were kept on $\mathrm{G}_{14}$ throughout. 
Table 8. Expt 4. Urinary nitrogen output and total liver enzyme activities in rats changed from a diet containing gelatin ( $135 \mathrm{~g} / \mathrm{kg} ; G \mathrm{I} 4$ ) to a diet containing casein ( $135 \mathrm{~g} / \mathrm{kg}$; C I4)

\begin{tabular}{|c|c|c|}
\hline & $\begin{array}{c}\text { Gr4 } \\
\text { throughout }\end{array}$ & $\begin{array}{c}36 \text { h after change } \\
\text { from Gi } 4 \text { to } \\
\text { Ci4t }\end{array}$ \\
\hline \multicolumn{3}{|l|}{ Urinary $\mathrm{N}$ output (mg/rat per $\mathrm{h}$ ) } \\
\hline Mean & $8 \cdot 75$ & $3 \cdot 17$ \\
\hline SD & 0.70 & - \\
\hline No. of collection periods & 8 & 2 \\
\hline Body-weight* (g) & 70 & 86 \\
\hline No. of rats & 2 & 3 \\
\hline \multicolumn{3}{|c|}{ Total enzyme activity (units/liver) $\dagger$} \\
\hline Arginase & 3920 & 5070 \\
\hline Argininosuccinate lyase & $19 \cdot 0$ & 24.0 \\
\hline Argininosuccinate synthetase & 10.3 & I 35 \\
\hline Glutamic dehydrogenase & 78 & 89 \\
\hline Alanine aminotransferase & 152 & 178 \\
\hline Aspartate aminotransferase & 289 & 369 \\
\hline
\end{tabular}

* At time of killing.

+ For arginase, argininosuccinate lyase and argininosuccinate synthetase, one unit of activity is the amount of enzyme catalysing the formation of $\mathrm{I} \mu \mathrm{mol}$ urea $/ \mathrm{min}$ at $38^{\circ}$. For glutamate dehydrogenase, alanine and aspartate aminotransferases, one unit of activity is the amount of enzyme catalyzing the oxidation of $\mathrm{I} \mu \mathrm{mol} \mathrm{NADH} / \mathrm{min}$ at $25^{\circ}$.

$\ddagger$ Urine collected from $24-36 \mathrm{~h}$ after change of diet.

Table 9. Expt 5. Urinary nitrogen output and total liver enzyme activity in rats given diets containing as protein source gelatin ( $\left.135 \mathrm{~g} / \mathrm{kg} ; \mathrm{G}_{\mathrm{I}} 4\right)$ or casein $\left(23 \circ \mathrm{g} / \mathrm{kg} ; \mathrm{C}_{23}\right)$

$\begin{array}{lcc}\text { Urinary N output (mg/rat per h) } & 8 \cdot 15 & 7 \cdot 88 \\ \text { No. of collection periods* } & 4 & 4 \\ \text { Body-weight }(\mathrm{g}) & \mathrm{II} 5 & \mathrm{r} 3 \mathrm{I} \\ \text { No. of rats } & 6 & 6 \\ \text { Enzyme activity (units/liver)t } & & \\ \quad \text { Arginase } & 6650 & 7200 \\ \text { Argininosuccinate lyase } & 29 \cdot 2 & 33 \cdot 5 \\ \text { Argininosuccinate synthetase } & 16 \cdot 3 & 18 \cdot 8 \\ \text { Glutamic dehydrogenase } & 122 & 132 \\ \text { Alanine aminotransferase } & 252 & 277 \\ \text { Aspartate aminotransferase } & 450 & 502\end{array}$

* Urine collected over periods of $24 \mathrm{~h}$.

$\uparrow$ At time of killing.

$\ddagger$ For arginase, argininosuccinate lyase and argininosuccinate synthetase, one unit of activity is the amount of enzyme catalysing the formation of I $\mu \mathrm{mol}$ urea $/ \mathrm{min}$ at $38^{\circ}$. For glutamate dehydrogenase, alanine and aspartate aminotransferases, one unit of activity is the amount of enzyme catalysing the oxidation of $1 \mu \mathrm{mol} \mathrm{NADH} / \mathrm{min}$ at $25^{\circ}$.

In this experiment no rats were maintained throughout on casein. Urine and faeces were collected for two $12 \mathrm{~h}$ periods before, and for three periods after, the change of diet. Three rats were killed at the end of each period after the diet change. To avoid possible effects of diurnal rhythms of enzyme activity the timing was arranged so that all rats were killed at mid-day. Table 8 shows the urinary $N$ and the total enzyme 


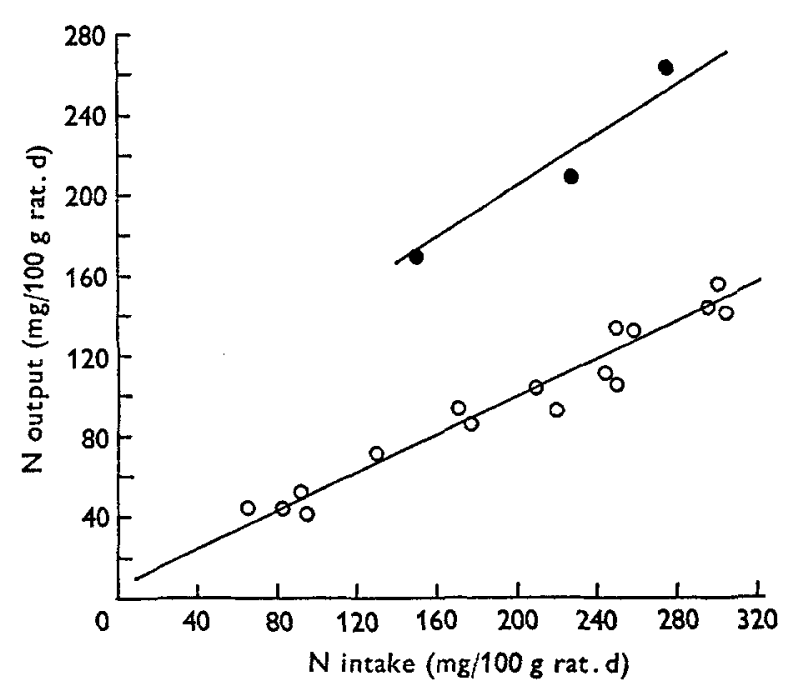

Fig. 7. Expts $1-5$. Relationship between urinary nitrogen output and $\mathrm{N}$ intake in rats given $45, \mathrm{I} 35$ or $230 \mathrm{~g}$ casein $/ \mathrm{kg} \operatorname{diet}(\mathrm{O})$ or $135 \mathrm{~g}$ gelatin $/ \mathrm{kg}$ diet (O). Results from all experiments.

activities in the group maintained throughout on the $\mathrm{G} \mathrm{I}_{4}$ diet, and $36 \mathrm{~h}$ after the transfer in the group transferred from $\mathrm{G}_{14}$ diet to $\mathrm{C}_{14}$ diet. Measurements were made at 12 and $24 \mathrm{~h}$; but these are not included in Table 8 since they add little further information. In spite of the large fall in urinary $N$, there were no significant changes in enzyme activity/g liver. Since the rats on transfer from the $\mathrm{G}_{14}$ diet to $\mathrm{C}_{14}$ diet began to gain weight, there were in fact increases in total enzyme activity/liver.

Expt 5. Casein was given at the level of $230 \mathrm{~g} / \mathrm{kg} \operatorname{diet}\left(\mathrm{C}_{23}\right)$, so that the urinary $\mathrm{N}$ excretion should be approximately the same as that obtained with the diet containing I35 $\mathrm{g}$ gelatin $/ \mathrm{kg}$ (G I4). Six rats were given each diet in amounts of $10 \mathrm{~g} / \mathrm{d}$ for Io d, and were then killed. Urinary $N$ output was measured for the last $3 \mathrm{~d}$. Table 9 shows that urinary $\mathrm{N}$ expressed as $\mathrm{mg} / \mathrm{rat}$ per $\mathrm{h}$ was approximately the same in the two groups. The total enzyme activities were higher in the group given $\mathrm{C}_{23}$ than in that given $\mathrm{G}_{\mathrm{I}}$.

\section{Comparison of different experiments}

The five experiments described above were done at different times on rats with different initial weights. If different experiments are to be compared, it is necessary to consider how consistent the results are. Fig. 7 shows the relation between $\mathrm{N}$ intake and urinary $\mathrm{N}$ excretion, both expressed in $\mathrm{mg} / \mathrm{roO} \mathrm{g}$ body-weight. There is clearly a consistent relationship, both with casein and with gelatin as the source of dietary protein.

Table Io summarizes the values for arginase activity in units/g liver for all experiments. It is evident that the results are comparable from one experiment to another. In Fig. 8 the total activity of the six enzymes is plotted against the dietary intake of casein. The increases are linear with increasing casein intake. However, if both enzyme activities and casein intakes are related to bodyweight, then the increase in activity falls off at higher levels of intake. This point is illustrated in detail for 
Table 10. Mean values and ranges for arginase activity (units $\uparrow \times 10^{3} / g$ liver) in Expts r-5 for control rats given diets containing $45\left(C_{5}\right), \mathrm{I}_{35}\left(C_{14} C_{4}\right)$ or $230\left(C_{23}\right) \mathrm{g}$ casein $/ \mathrm{kg}$ or I 35 g gelatin $/ \mathrm{kg}\left(\begin{array}{l}G \\ \mathrm{I}\end{array}\right)$

\section{Diet}

$\begin{array}{ccccc}\text { Expt no.* } & \mathrm{C}_{5} & \mathrm{C}_{14} & \mathrm{G}_{14} & \mathrm{C}_{23} \\ \mathrm{I} & 25 & 62 & - & - \\ & (22-27) & (58-64) & & - \\ 2 & 22 & 64 & - & - \\ & (20-25) & (60-68) & & \\ 3 & 24 & 65 & 64 & - \\ 4 & (21-27) & (61-70) & (61-68) & \\ 4 & - & 64 & 67 & - \\ 5 & - & (60-68) & (64-69) & \\ & & - & 68 & 78 \\ & & & (65-72) & (74-84)\end{array}$

* For details of Expt $1-5$ see 'Experimental and Results'.

+ One unit of activity is the amount of enzyme catalysing the formation of $\mathrm{I} \mu \mathrm{mol} \mathrm{urea} / \mathrm{min}$ at $38^{\circ}$
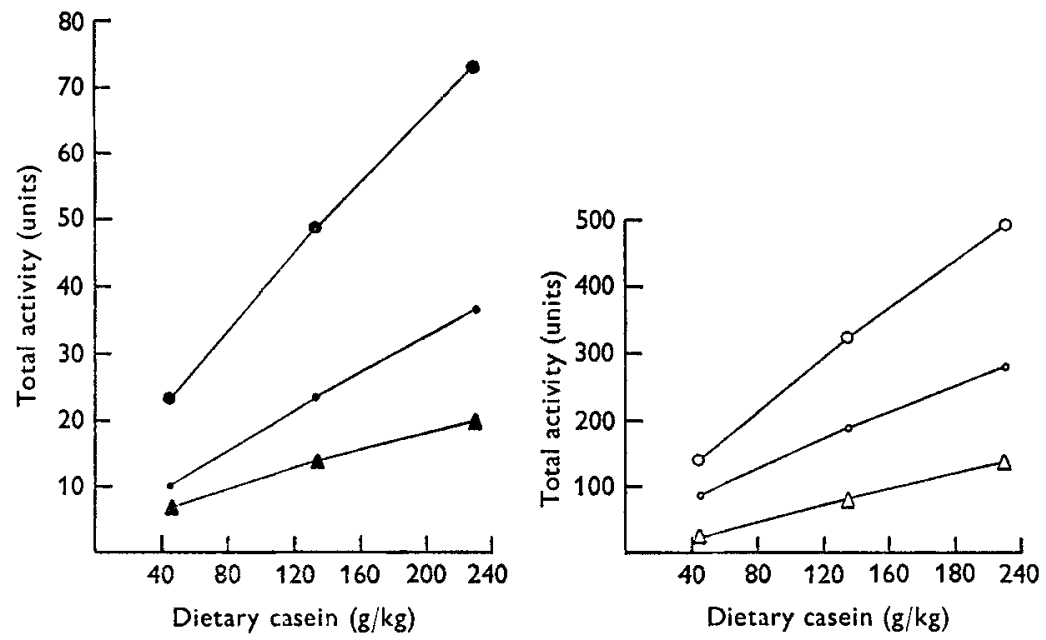

Fig. 8. Expts 1-5. Total activity for six enzymes relative to casein content of diet in rats. (•) Arginase $\left(\times \mathrm{ro}^{3}\right),(\mathbf{E})$ argininosuccinate lyase, $(\boldsymbol{\Delta})$ argininosuccinate synthetase, $(O)$ aspartate aminotransferase, $(\square)$ alanine aminotransferase, $(\triangle)$ glutamate dehydrogenase. Mean values for pooled results from different experiments. For arginase, argininosuccinate lyase and argininosuccinate synthetase, one unit of activity is the amount of enzyme catalysing the formation of one $\mu \mathrm{mol}$ urea $/ \mathrm{min}$ at $38^{\circ}$; for aspartate and alanine aminotransferases and glutamate dehydrogenase, one unit of activity is the amount of enzyme catalysing the oxidation of I $\mu \mathrm{mol} \mathrm{NADH} / \mathrm{min}$ at $25^{\circ}$.

arginase in Fig. 9. Evidently, as protein intake rises there is a relatively greater increase in total body protein than in enzyme protein. Fig. Io shows the relationship between arginase activity and $\mathrm{N}$ excretion. Figs. 9 and $\mathrm{I}$, which include the results of all experiments, also indicate the degree of variability which was found in these relationships. 


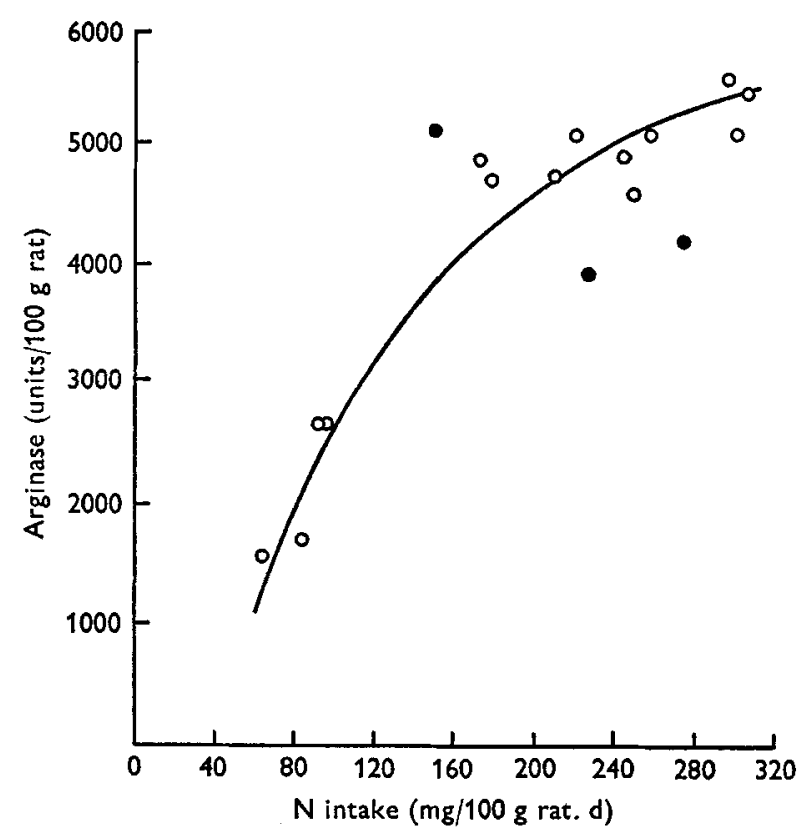

Fig. 9. Expts I-5. Relationship between arginase activity and nitrogen intake in rats given diets containing different amounts and different sources of protein. $O$, casein; 9 , gelatin; (-) the relationship between arginase activity and $\mathrm{N}$ intake in rats given casein as the source of protein. One unit of arginase activity is the amount of enzyme catalysing the formation of I $\mu \mathrm{mol}$ urea/min at $38^{\circ}$.

\section{DISCUSSION}

A number of previous studies have been made of the adaptation of urea cycle enzymes to different levels of protein intake (Ashida \& Harper, 196r; Muramatsu \& Ashida, 1962; Schimke, 1962; Szepesi \& Freedland, 1969). In these experiments very large amounts of casein were given to produce the maximum adaptation. In some instances enzyme activities were compared after adaptation periods of several days. In others, measurements were made on successive days. Thus on changing from $30 \%$ to $60 \%$ casein, the peak arginase activity was reached in $8 \mathrm{~d}$ (Schimke, 1962); on changing from $\circ \%$ to $90 \%$ casein, it was reached in $5 \mathrm{~d}$ (Szepesi \& Freedland, I 969). In the work described here the protein concentration in the diet was varied within more normal limits. Moreover, we were interested not so much in the actual levels of enzyme activity as in the rate at which the new level was reached when the protein intake was changed, and the relation between this rate and the rate of change of urinary $\mathrm{N}$ output. Therefore measurements were made at short intervals, usually $6 \mathrm{~h}$, over a period of $30-36 \mathrm{~h}$.

After the protein intake was changed, whether upwards or downwards, the new levels of both enzymes and urinary $\mathrm{N}$ were reached in about $3^{\circ} \mathrm{h}$. Broadly, therefore, they followed the same time course. However, if we try to relate $\mathrm{N}$ output to enzyme activity over shorter periods of time, e.g. in successive $6 \mathrm{~h}$ periods, there are discrepancies, which may perhaps be attributed to biological variability and error.

The initial experiments (nos. I and 2) suggested that one might postulate a cause 


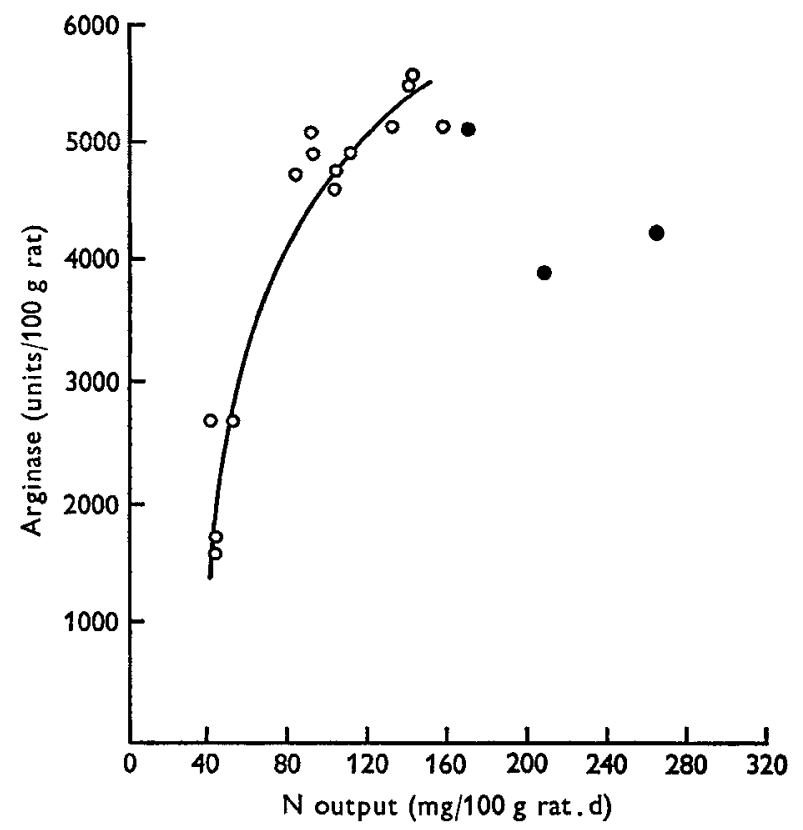

Fig. IO. Expts I-5. Relationship between arginase activity and urinary nitrogen output in rats given diets containing different amounts and different sources of protein. $O$, casein; 0 , gelatin; (-) the relationship between arginase activity and $N$ output in rats given casein as the source of protein. One unit of arginase activity is the amount of enzyme catalysing the formation of $\mathrm{i} \mu \mathrm{mol}$ urea at $38^{\circ}$.

and effect relationship between changes in urea cycle enzymes and output of urea $\mathrm{N}$. This would be an important part of the mechanism of adaptation to changes in protein intake. The later experiments, however, showed that this explanation is too simple, since when gelatin was the source of dietary protein there were large increases in urinary $\mathrm{N}$ without comparable increases in enzyme activity. Other workers have found this kind of dissociation. Kiriyama \& Iwao (1969) showed that when rats were fed diets containing different amounts of diammonium citrate, there was an inverse relationship between liver arginase activity and urea excretion. Muramatsu \& Ashida (quoted by Kiriyama \& Iwao, I969) showed that when proteins of different quality were fed at the same level, arginase activity was always higher in rats given high-quality protein, although this was accompanied by decreased urea excretion. Similarly, Muramatsu \& Nakagawa (I97I) found that at equal intakes of protein, the poorer the quality of the protein the lower the arginase content of the liver. Perhaps, therefore, a poor-quality protein cannot promote enzyme synthesis because it does not supply a balanced amino acid mixture.

The present results suggest that the animal is able to produce more urea without an increase in the amounts of the urea cycle enzymes because the potential capacity of the enzyme systems is normally not fully utilized. This point is illustrated in Table I $I$, in which a comparison is made between the actual amounts of urea excreted at different levels of protein intake and the potential capacity for urea production, as measured in vitro. Argininosuccinate synthetase has been chosen for this comparison, 
Table I I. Actual and potential rates of urea synthesis in relation to nitrogen intake in rats

\begin{tabular}{|c|c|c|c|c|}
\hline \multirow[b]{2}{*}{$\begin{array}{l}\text { Protein content of } \\
\text { diet }(\mathrm{g} / \mathrm{kg})\end{array}$} & \multicolumn{3}{|c|}{ Casein } & \multirow[t]{2}{*}{ Gelatin } \\
\hline & 50 & I35 & 230 & \\
\hline $\mathrm{N}$ intake $(\mathrm{mg} / \mathrm{d})$ & 80 & 224 & 380 & 200 \\
\hline No. of rats & I 2 & 17 & 6 & 10 \\
\hline Mean body-weight (g) & IIO & 115 & 130 & 100 \\
\hline $\begin{array}{l}\text { Urea excretion } \\
(\mu \mathrm{mol} / \mathrm{h}) \text { (actual } \\
\text { rate) }\end{array}$ & 108 & 242 & 282 & 333 \\
\hline $\begin{array}{l}\text { Total argininosuccinate } \\
\text { synthetase activity } \\
\text { ( } \mu \mathrm{mol} / \mathrm{h}) \\
\text { (potential rate) }\end{array}$ & 250 & 707 & I 128 & 835 \\
\hline$\frac{\text { Actual rate }}{\text { Potential rate }}(\%)$ & 43 & 34 & 25 & $4^{\circ}$ \\
\hline
\end{tabular}

because its activity in vitro is the lowest of the enzymes measured, and for this reason it has been considered by many authors to be rate-limiting. Table I I shows that the utilization or loading of the enzyme system (actual rate:potential rate) decreases as casein intake increases. This suggests that when adaptive changes in enzyme activity occur in response to an increase in $\mathrm{N}$ intake, there is a tendency to overshoot, producing a larger margin of safety; when $\mathrm{N}$ intake is decreased, the opposite occurs.

In all experiments the activities of the three enzymes of the urea cycle and of the three enzymes which make amino groups available for entry into the cycle changed at essentially the same rate and to the same extent. This concerted change in the urea cycle enzymes is a remarkable phenomenon which, in varying degree, has been observed in response to three different kinds of stimuli: diet (Schimke, 1962); hormones (McLean \& Gurney, 1963); and metamorphosis (Wixom, Reddy \& Cohen, 1972). Wixom et al. (1972) point out that the changes involve the intramitochondrial enzymes carbamoylphosphate synthase $\left(\begin{array}{lll}E C & \mathbf{2 . 7 . 2 . 5}\end{array}\right)$ and ornithine carbamoyltransferase $(E C 2.1 .3 .3)$ as well as the cytoplasmic enzymes arginase, argininosuccinate lyase and argininosuccinate synthetase. They regard this synchrony as evidence of biochemical differentiation, which, at least in the instance of the metamorphosing tadpole, may presumably be regarded as a once-and-for-all event. In concept this is rather different from the more rapid, reversible adaptations described in the present experiments. In both instances, however, the synchrony may represent the expression of a common genome.

Many other workers have observed changes in the activity of GDH and of the aminotransferases produced by diet (Rosen, Roberts \& Nicol, I959; Muramatsu \& Ashida, 1962; Schimke, 1962). In the experiments of Schimke (1962) the activities of GPT and GOT increased with increasing dietary protein, but that of GDH did not. McLean \& Gurney (1963) found that after adrenalectomy GDH fell, but GOT remained unchanged. As far as we are aware, the close parallelism found in the present experiments 
between the rate and extent of changes in GDH, GPT, GOT and the urea cycle enzymes has not previously been observed. No explanation is offered for this phenomenon; it is equally remarkable whether it represents changes in amount of enzyme or in enzyme activation.

We found, in agreement with others (Brown \& Cohen, 1959; Schimke, 1962; McLean \& Gurney, 1963) that argininosuccinate synthetase activity in vitro was the lowest of the three urea cycle enzymes which were measured. This activity, in livers from rats given $\mathrm{I} 35 \mathrm{~g}$ casein/ $\mathrm{kg}$ diet, was equivalent to a production of about $200 \mathrm{mg}$ urea $\mathrm{N} / \mathrm{d}$, while the actual excretion in vivo was about $100 \mathrm{mg}$ urea $\mathrm{N} / \mathrm{d}$. These two rates are of the same order of magnitude. By contrast, the activity of arginase in vitro was some 300 times that of the synthetase. However, it has been pointed out that if arginase is assayed under the same conditions as the synthetase, i.e. at neutral $\mathrm{pH}$ and without excessive $\mathrm{Mn}^{2+}$, its activity is about 100 times less than under the usual assay conditions (McLean \& Gurney, 1963). Thus assays in vitro, under conditions designed to produce maximum activity, give little indication of the relative activities in vivo and hence of which enzyme is rate limiting.

The present experiments provide no direct evidence of whether the enzyme changes represent changes in activity or in amount of enzyme protein. Under the conditions of assay in vitro many factors which may modify activity in vivo, such as substrate concentration, feed-back inhibition or intracellular compartmentation, are removed. The assay, therefore, measures the potential capacity of the enzyme. Much of the work on enzyme induction, summarized by Schimke (1970) and by Kenney (1970), indicates indirectly that induced changes in enzyme activity are brought about mainly through changes in the amount of enzyme protein. In the instance of arginase Schimke (1964) has demonstrated this direct by immunochemical assay of the enzyme. On the other hand, some enzymes, e.g. carbamoylphosphate synthase (EC 2.7.2.5) (Virden, 1972) and L-serine dehydratase ( $E C_{4}$.2 . I . I3) (Inoue \& Pitot 1970 ), exist in two forms which may represent active and inactive forms of the enzyme, so that an increase in activity may result from activation of the precursor rather than from synthesis of new enzyme.

The kinetic analysis which was attempted did not fit the classical model exactly, since many of the semilog plots were not linear. This does not necessarily mean that the concepts on which the model is based do not apply. A likely explanation is that the values chosen for the base-line rates of enzyme synthesis were not appropriate. The observed facts (Fig. 7) could be explained on the basis of changes in the amounts of enzyme protein which resulted almost entirely from changes in synthesis rate. The breakdown rate, represented by the slope of the semilog plot, appeared to be the same whether activity was increasing, or decreasing. This is consistent with many studies of enzyme induction: changes in the rate of synthesis seem in general to be more important than changes in the rate of breakdown.

If the decay of enzyme activity represents breakdown of enzyme protein, then it appears that under the conditions of these experiments the enzymes studied had halflives of 8-10 h. This is very much shorter than the value of about $5 \mathrm{~d}$ obtained by Schimke (1964) for the half-life of arginase. His estimate was obtained from the decay curve of the specific protein isolated immunochemically after it had been labelled 
with $\left[6-{ }^{14} \mathrm{C}\right]$ arginine. There is evidence that the $\mathrm{C} 6$ (guanidine carbon) atom in arginine is re-utilized to the extent of about $25 \%$ (Millward, 1970), but this is not enough to explain the discrepancy in half-lives. Szepesi \& Freedland (1969) estimated the half-life of arginase as $30 \mathrm{~h}$ from measurements of the rate of increase of activity during adaptation to a high-protein diet. Muramatsu \& Nakagawa (1971) in experiments similar to ours, obtained estimates of $16-\mathrm{r} 8 \mathrm{~h}$. Freedland (1968) has summarized estimates of half-lives of several enzymes calculated from changes in activity during adaptation. Where comparisons are possible, the half-lives are much longer than those found in the present experiments, e.g. $35 \mathrm{~h}$ for GPT and $37-60 \mathrm{~h}$ for GOT (Szepesi \& Freedland, I 967). We have no explanation for these differences. One possibility is differences in strains of animals. D. J. Millward (unpublished results) has obtained preliminary evidence of differences in the catabolic rate of muscle proteins between hooded and albino rats.

In conclusion, any attempt to explain the relationship between $\mathrm{N}$ intake, urea output and activity of the urea cycle enzymes must take account of the fact that under physiological conditions the amount of amino- $\mathrm{N}$ entering the liver from food is considerably less than that produced by the breakdown of body protein (Waterlow, I968). In the fasting rat the flux from protein breakdown amounts to about $3 \mathrm{~g}$ protein/100 $\mathrm{g}$ body-weight per $d$ (Waterlow \& Stephen, I967). If the protein intake is changed from 0.5 to $\mathrm{I} \cdot 5 \mathrm{~g} / \mathrm{roo} \mathrm{g}$ rat per $\mathrm{d}$, the total flux would increase from 3.5 to $4.5 \mathrm{~g} / \mathrm{ro0} \mathrm{g}$ per $\mathrm{d}$, an increase of $30 \%$. As the present results show, this small change in flux is accompanied by a $2-3$-fold increase in activity of the enzymes. Secondly, the system for catabolizing amino acids and degrading them to urea does not operate in isolation, but rather in competition with the opposing pathway of amino acid uptake into protein. Therefore the amount of amino- $\mathrm{N}$ entering the urea cycle will depend not only on the supply but also on the activity of the activating enzymes which catalyse the first step in protein synthesis. It has been shown that on low-protein diets the activity of these enzymes in liver increases (Gaetani, Paolucci, Spadoni \& Tomassi, I964; Stephen, 1968). The control of flow through the two pathways, of synthesis and degradation, must therefore depend on the relative activities and affinities of the two sets of enzymes. How these in their turn are regulated to meet the needs of the organism remains mysterious. It is very likely that hormonal changes are implicated, since it has been shown that the activities of the urea cycle enzymes are increased by administration of cortisol and decreased by adrenalectomy (McLean \& Gurney, r963; Schimke, 1963). However, these are rather extreme situations, and we still do not know whether cortisol has a regulatory effect under physiological conditions.

\section{REFERENCES}

Archibald, R. M. (1945). F. biol. Chem. r57, 507.

Ashida, K. \& Harper, A. E. (I96r). Proc. Soc. exp. Biol. Med. ro7, 51.

Bergmeyer, H. U. (1963). Methods of Enzymic Analysis p. I I. New York: Academic Press.

Brown, G. W., Brown, W. R. \& Cohen, P. P. (1959). F. biol. Chem. 234, I 775.

Brown, G. W. \& Cohen, P. P. (1959). F. biol. Chem. 234, I769.

Chan, H. (1968). Br.f. Nutr. 22, 315.

Das, T. K. (1972). Proc. Nutr. Soc. 31, 78A. 
Fisher, H. (1965). f. Nutr. 85, 181,

Folin, O. (1905). Am. F. Physiol. r3, 66.

Freedland, R. A. (1968). Life Sci. 7, part 2, 499.

Gaetani, S., Paolucci, A. M., Spadoni, M. A. \& Tomassi, G. (1964). F. Nutr. 84, 173.

Gopalan, C. \& Narasinga Rao, B. S. (I966). F. Nutr. 90, 213.

Harper, A. E. (1965). Can. F. Biochem. Physiol. 43, I589.

Inoue, H. \& Pitot, H. C. (1970). Adv. Enzyme Regulation 8, 289.

Kenney, F. T. (1970). In Mammalian Protein Metabolism Vol. 4, p. I3I [H. N. Munro, editor]. New York: Academic Press.

Kiriyama, S. \& Iwao, H. (1969). Agric. biol. Chem. F. 33, 1483.

Kumar, I., Land, D. G. \& Boyne, A. W. (1959). Br. $¥$. Nutr. 13, 320.

McLean, P. \& Gurney, M. W. (1963). Biochem. F. 87, 96.

Martin, C. J. \& Robison, R. (1922). Biochem. F. 16, 407.

Millward, D. J. (1970). Clin. Sci. 39, 577.

Muramatsu, K. \& Ashida, K. (1962). F. Nutr. 76, 143.

Muramatsu, K. \& Nakagawa, T. (I97I). Agric. biol. Chem. J. 35, I 594.

Payne, P. R. \& Stewart, R. J. C. (1972). Lab. Anim. 6, I35.

Pitot, H. C., Potter, V. R. \& Morris, H. P. (I96I). Cancer Res. 2I, I00I.

Rosen, F., Roberts, N. R. \& Nicol, C. A. (1959). F. biol. Chem. 234, 476.

Schimke, R. T. (1962). F. biol. Chem. 237, 459.

Schimke, R. T. (1963). F. biol. Chem. 238, ror2.

Schimke, R. T. (1964). F. biol. Chem. 239, 3808.

Schimke, R. T. (1970). In Mammalian Protein Metabolism Vol. 4, p. I77 [H. N. Munro, editor]. New York: Academic Press.

Scrimshaw, N. S., Hussein, M. A., Murray, E., Rand, W. M. \& Young, V. R. (1972). f. Nutr. 102, I 595 .

Segal, H. L. \& Kim, Y. S. (1963). Proc. natn. Acad. Sci. U.S.A. 50, 912.

Stephen, J. M. L. (1968). Br. F. Nutr. 22, I 53.

Stephen, J. M. L. \& Waterlow, J. C. (1968). Lancet i, I 18.

Szepesi, B. \& Freedland, R. A. (1967). F. Nutr. 93, 301.

Szepesi, B. \& Freedland, R. A. (1969). Life Sci. 8 part 2, 1067.

Technicon Instruments Corporation (1967). Technicon Methods Sheet $N 3 b$. New York: Technicon Instruments $\mathrm{Co}$.

Virden, R. (1972). Biochem. F. 127, 503.

Waterlow, J. C. (1968). Lancet ii, 1091.

Waterlow, J. C. \& Patrick, S. J. (1954). Ann. N. Y. Acad. Sci. 57, 750.

Waterlow, J. C. \& Stephen, J. M. L. (1967). Clin. Sci. 33, 489 .

Waterlow, J. C., Neale, R. J., Rowe, L. \& Palin, I. (1972). Am. F. clin. Nutr. 25, 37 I

Wixom, R. L., Reddy, M. K. \& Cohen, P. P. (1972). F. biol. Chem. 247, 3684.

Wootton, I. D. P. (1964). Micro-analysis in Medical Biochemistry. London: Churchill. 